Secret History 



\section{Secret History}

THE CIA'S CLASSIFIED ACCOUNT OF ITS OPERATIONS IN

GUATEMALA，I 952 - I 954

SECOND EDITION

Nick Cullather

with an introduction by the author and an Afterword by Piero Gleijeses

Stanford University Press

Stanford, California 2006 


\author{
Stanford University Press \\ Stanford, California \\ Preface, Introduction, Afterword, Notes \\ to Appendixes $\mathrm{C}$ and $\mathrm{D}$, and Index \\ (C) I999 and 2006 by the Board of Trustees of \\ the Leland Stanford Junior University \\ Printed in the United States of America
}

Library of Congress Cataloging-in-Publication Data

Cullather, Nick

Secret history : the CIA's classified account of its operations in Guatemala, I952-I954 / Nick Cullather; with an introduction by the author and an Afterword by Piero Gleijeses-2nd ed.

p. $\mathrm{cm}$.

Includes bibliographical references and index.

ISBN-I3: 978-0-8047-5467-5 (cloth : alk. paper). -

ISBN-I 3: 978-0-8047-5468-2 (pbk. : alk. paper)

I. Guatemala-History-I945-I985. 2. United States-

Central Intelligence Agency. 3. Guatemala-History-

Revolution, I954. 4. Arbenz Guzmán, Jacobo, I9I3-I97I. 5. United States-Relations-Guatemala. 6. GuatemalaRelations-United States. I. Title.

FI466.5.A688C $85 \quad 2006$

972.8 IO5' $2-\mathrm{dc} 22^{2}$

20060103 I 5

This book is printed on acid-free, recycled paper. 